\title{
Kesehatan Mental Warga Binaan Pemasyarakatan Berdasarkan Tingkat Kualitas Hidup: an overview
}

\author{
Prystia Riana Putri ${ }^{1}$, Artika Nurrahima ${ }^{2}$, Megah Andriany ${ }^{3}$ \\ ${ }^{1}$ Mahasiswa Magister Keperawatan, Fakultas Kedokteran, Universitas Diponegoro, Semarang \\ Email: prystiarputri@gmail.com \\ 2 Departemen Ilmu Keperawatan, Fakultas Kedokteran, Universitas Diponegoro, Semarang \\ ${ }^{3}$ Departemen Ilmu Keperawatan, Fakultas Kedokteran, Universitas Diponegoro, Semarang
}

\begin{abstract}
Abstrak. Perubahan standar kehidupan Warga Binaan Pemasyarakatan (WBP) yang tidak sesuai dengan target pencapaian memberikan pengaruh terhadap kesehatan mental khususnya kualitas hidup. Namun, penelitian yang membahas mengenai kualitas hidup berdasarkan empat domain (fisik, psikologis, hubungan sosial, dan lingkungan) di Lapas belum tersedia sehingga penelitian ini perlu dilakukan untuk melihat gambaran kualitas hidup WBP. Penelitian menggunakan desain cross sectional dengan jumlah sampel 100 WBP laki-laki yang didapatkan melalui teknik systemic random sampling di salah satu Lapas Provinsi Jawa Tengah tahun 2019. Menghuni Lapas maksimal 18 bulan, tidak mendapat kunjungan keluarga secara langsung menjadi kriteria penentuan sampel. Instrumen yang digunakan dalam penelitian ini adalah WHOQOL-BREF. Hasil penelitian menunjukkan bahwa kualitas hidup berdasarkan domain fisik WBP $63 \%$, psikologis $63 \%$, hubungan sosial $56 \%$, dan lingkungan $50 \%$. Simpulan yang dapat diambil adalah bahwa kesehatan mental WBP dapat dilihat dari gambaran kualitas hidup. Hasil penelitian ini akan memudahkan perawat komunitas dalam menentukan masalah dan intervensi keperawatan yang tepat dalam menangani permasalahan di Lapas.
\end{abstract}

Kata kunci: Penjara, perawat Lapas, kualitas hidup, warga binaan.

\section{Mental Health Prisoners Based On Quality Of Life: An Overview}

Abstract. Changes in prisoners living standards that did not accordance with the achievement targets have an impact on mental health especially their quality of life. However, research that discusses the quality of life based on four domains (physical, psychological, social relations, and environment) in prison is not yet available so this research needs to be done to see an overview of prisoners quality of life. This study used a cross sectional design with 100 male prisoners as sample that obtained through systemic random sampling techniques in one of Central Java Prison in 2019. Inhabiting the prison for a maximum of 18 months, no direct family visits were the criteria for determining the sample. The instrument used in this study was WHOQOL-BREF. The results showed that quality of life was based on the physical domain of WBP 63\%, psychological $63 \%$, social relations $56 \%$, and environment $50 \%$. The conclusion is mental health can be know from quality of life overview. This research can facilitate community nurses in determining problems and appropriate nursing interventions in dealing with quality of life problems in correctional institutions. Keywords: Correctional nursing, inmates, prison, quality of life

\section{Pendahuluan}

Warga binaan pemasyarakatan (WBP) mengalami peningkatan setiap tahunnya. Sistem database di suatu Lembaga pemasyarakatan (Lapas) Indonesia menyatakan bahwa terdapat 1.402 WBP ditahun 2017, 1.704 WBP ditahun 2018, dan 1.931 WBP pada Oktober 2019 ('Sistem Database Pemasyarakatan. Laporan penghuni lapas', 2017; Sistem Database Pemasyarakatan. Laporan penghuni lapas, 2018; 'Sistem Database Pemasyarakatan. Laporan penghuni lapas', 2019). Tingginya angka WBP di Lapas mempengaruhi berbagai aspek kehidupan.

WBP dihadapkan dengan perubahan situasi, kondisi, serta tuntutan untuk mampu 
beradaptasi dengan cepat di dalam Lapas (Kalonji et al., 2017). Kemampuan WBP dalam menghadapi setiap perubahan ketika berada di Lapas berpengaruh terhadap kesehatan mental (Hartley and Maclean, 2008).

Studi pendahuluan yang dilakukan di sebuah Lapas Jawa Tengah didapatkan hasil bahwa perubahan status peran, jauh dari kerabat, dan adanya perasaan tidak puas terhadap kondisi Lapas mengakibatkan peningkatan ketidaknyamanan dan ketenangan. Ketidakmampuan WBP untuk menerima keadaan yang tidak sesuai dengan standar kehidupan yang sudah ditetapkan dapat mempengaruhi kualitas hidup (Ventegodt, Merrick and Andersen, 2003; Emmons and Stern, 2013).

Kualitas hidup merupakan persepsi WBP dalam melihat kehidupan yang dihadapi dan dinilai melalui empat domain yakni fisik, psikologis, hubungan sosial, dan lingkungan (WHO, 1998; WHOQOL, 1998). WBP dengan perasaan tertekan, cemas, tidak mampu mempertahankan pemikiran positif dan adanya kekhawatiran terus menerus akan berdampak pada kondisi kesehatan fisik dan psikologis (Felce and Perry, 1995; Vahedi, 2010; Kelly, 2016). Adapun perasaan negatif yang dimiliki WBP akan memberikan pengaruh terhadap jalinan hubungan sosial dan lingkungan dimana WBP berada (Liebling, 2008; Vahedi, 2010). Penelitian

\section{Metode}

Penelitian ini dilakukan menggunakan desain cross sectional, terdiri dari 100 WBP yang dipilih melalui systemic random sampling di salah satu Lapas Provinsi Jawa Tengah. Penelitian dilakukan pada bulan September 2019. Kriteria inklusi penentuan sampel adalah WBP laki-laki, telah menghuni Lapas maksimal 18 bulan, tidak mendapat kunjungan keluarga secara langsung. mengungkapkan bahwa proses penerimaan WBP terhambat karena munculnya perasaan negatif akan diri, merasa tidak mampu melakukan yang terbaik, hingga kehilangan harapan positif akan masa depan (DolińskaZygmunt and Mokrzyńska, 2013; Bruce and Larweh, 2017).

Penelitian kualitas hidup sebelumnya pernah dilakukan oleh Hajar (2017) terkait hubungannya dengan harga diri yang dimiliki WBP dan Pheny, Raymondalexas and Rahmat (2014) terkait kecerdasaran adversitas WBP. Namun, penelitian tersebut tidak berfokus terhadap tingkat kualitas hidup sebelum dihubungkan dengan variabel lainnya dan penelitian tersebut dilakukan di Lapas Narkotika sehingga populasi yang dilihat akan berbeda dengan penelitian ini.

Tingkat kualitas hidup yang dimiliki WBP menjadi salah satu acuan perawat komunitas dalam memberikan intervensi yang tepat karena skrining kualitas hidup dapat menggambarkan kondisi kesehatan mental WBP yang sesungguhnya. Namun, penelitian yang membahas mengenai kualitas hidup berdasarkan empat domain kualitas hidup di Lapas belum tersedia. Oleh karena itu, penelitian ini akan memberikan gambaran mengenai tingkat kualitas hidup yang dimiliki WBP di Lapas melalui empat domain yang saling mempengaruhi.

WBP mengisi instrumen WHOQOLBREF untuk mengetahui tingkat kualitas hidup yang dimiliki selama berada di dalam Lapas. Uji validitas dan reliabilitas telah dilakukan pada instrumen WHOQOLBREF dan telah dinyatakan valid dan reliabel dengan nilai $r=0,466-0,786$ dan nilai $\mathrm{R}=0,859$ (Pheny, Raymondalexas and Rahmat, 2014). Uji etik penelitian dilakukan ke Komite Etik Departemen Keperawatan 
Universitas Diponegoro dan dinyatakan lulus uji dengan nomor 61/EC/KEPK/D.Kep/IX/2019.

Data yang didapatkan di analisis menggunakan analisa univariat untuk

\section{Hasil Penelitian}

Instrumen

WHOQOL-BREF merupakan instrumen turunan dari WHOQOL-100 yang dibuat oleh WHO. WHOQOL-BREF memudahkan peneliti dalam melihat tingkat kualitas hidup dengan menyediakan butir pertanyaan yang lebih singkat. Penyesuaian skor dilakukan dengan

\begin{tabular}{clc}
\hline No & \multicolumn{1}{c}{ Domain } & Kualitas hidup \\
\hline 1 & Fisik & $63 \%$ \\
\hline 2 & Psikologis & $63 \%$ \\
\hline 3 & Hubungan sosial & $56 \%$ \\
\hline 4 & Lingkungan & $50 \%$ \\
\hline
\end{tabular}

Hasil skrining kualitas hidup pada tabel 1 menunjukkan bahwa WBP memiliki kualitas hidup dibawah standar kualitas

\section{Pembahasan}

Kualitas hidup WBP yang didapatkan dari hasil penelitian ternyata masih jauh dibawah standar kualitas hidup baik. Penurunan kualitas hidup yang terjadi pada WBP Laki-laki sejalan dengan penelitian Brennan-olsen,dkk (2017) dan Dijkers (2003) mengungkapkan bahwa faktor-faktor yang ditemui WBP laki-laki di Lapas seperti kehilangan kebebasan, perubahan standar kehidupan dan adanya perubahan status dan peran dapat mempengaruhi kualitas hidup.

Penelitian Felce \& Perry (1995) menyatakan bahwa penurunan kualitas hidup berdasarkan domain fisik terjadi karena WBP tidak mampu menerima keadaan kehidupan di Lapas dan menjadikan situasinya sebagai beban berat hingga menimbulkan perasaan tertekan. melihat gambaran kualitas hidup melalui empat domain (fisik, psikologis, hubungan sosial, dan lingkungan). Data disajikan dalam bentul tabel distribusi frekuensi berupa presentase (\%) hasil.

melakukan konversi pada tabel skor yang berada di WHOQOL-BREF ke skor WHOQOL-100 (WHO, 1996) sehingga hasil yang didapat pada penelitian ini berupa data deskriptif gambaran kualitas hidup yang meliputi empat domain kualitas hidup WHO.

Tabel 1. Hasil skrining kualitas hidup

hidup yang baik yakni dibawah 75\%. Penilaian tersebut berdasarkan hasil olah data instrumen yakni skor domain fisik sebesar $63 \%$, skor domain psikologis $63 \%$, skor domain hubungan sosial yakni $56 \%$, dan skor domain lingkungan sebesar $50 \%$.

Penelitian Bruce \& Larweh (2017) mengungkapkan bahwa penurunan kualitas hidup terjadi karena WBP tidak mampu beradaptasi tehadap situasi dan kondisi yang terjadi yakni perubahan lingkungan di Lapas yang berbeda dengan lingkungan tinggal sebelumnya. Kualitas hidup menjadi faktor terkait tinggi rendahnya kesehatan mental yang dimiliki WBP.

Penurunan kualitas hidup dari domain psikologis berdasarkan penelitian Vahedi (2010) menyatakan bahwa kondisi psikologis di Lapas dipengaruhi ketidakmampuan WBP dalam menjaga pemikiran positif karena dituntut dengan banyak perubahan yang tidak sesuai dengan harapan. 
Penurunan kualitas hidup dapat memberikan dampak negatif bagi WBP. Ketidakmampuan WBP dalam mempertahankan kualitas hidup dari domain lingkungan dan hubungan sosial Simpulan

Kualitas hidup berbanding lurus dengan kesehatan mental yang dimiliki WBP. Berdasarkan hasil penelitian dapat disimpulkan bahwa kualitas hidup WBP laki-laki yang tinggal di Lapas mengalami penurunan pada ke empat domain. Data

\section{Daftar Pustaka}

Brennan-olsen, S. L. et al. (2017) 'Maturitas poor quality of life in Australian men: Crosssectional associations with obesity, mobility, lifestyle and psychiatric symptoms', Maturitas. Elsevier, 103(January), pp. 32-36. doi: 10.1016/j.maturitas.2017.06.024.

Bruce, D. and Larweh, E. (2017) 'Self-esteem, needs satisfaction and psychological wellbeing of inmates at James Camp Prison in Ghana', International Journal of Humanities Social Sciences and Education, 4(9), pp. 32-39. doi: 10.20431/23490381.0409005 .

Dijkers, M. P. (2003) 'Individualization in quality of life measurement: Instruments and approaches', Archives of Physical Medicine and Rehabilitation, 84(4 SUPPL. 2), pp. 3-14. doi: 10.1053/apmr.2003.50241.

Dolińska-Zygmunt, G. and Mokrzyńska, K. (2013) 'Personal quality of life factors among imprisoned repeat offenders', Polish Journal of Applied Psychology, 11(4), pp. 109-122.

Emmons, R. A. and Stern, R. (2013) 'Gratitude

as a psychotherapeutic intervention', 69(8), pp. 846-855. doi: 10.1002/jclp.22020.

Felce, D. and Perry, J. (1995) 'Quality of life: Its seperti perilaku menarik diri, merasa kehilangan potensi, dan tumbuhnya perasaan tidak berdaya (Liebling, 2008; Brennan-olsen et al., 2017).

mengenai gambaran kualitas hidup WBP dapat memudahkan perawat komunitas dalam menentukan masalah dan intervensi keperawatan yang tepat secara efisien dan efektif berdasarkan penyebab terjadinya masalah kualitas hidup WBP berdasarkan domain.

definition and measurement', 16(1), pp. $51-74$.

Hajar, S. (2017) Hubungan harga diri dengan kualitas hidup narapidana di Lembaga Pemasyarakatan Narkotika Kelas IIa Yogyakarta. Yogyakarta: Fakultas Ilmu Kesehatan Universitas 'Aisyiyah.

Hartley, S. L. and Maclean, W. E. (2008) 'Coping strategies of adults with mild intellectual disability for stressful social interactions', Journal of Mental Health Research in Intellectual Disabilities, 1(2), pp. 109-127. doi: 10.1080/19315860801988426.

Kalonji, M. P. G. et al. (2017) 'Quality of life perception by inmates in the central prison of Mbuji-Mayi, Democratic Republic of Congo', International Journal of Medical Research \& Health Sciences, 6(12), pp. 4248.

Kelly, J. D. (2016) 'Your best life: Breaking the cycle: the power of gratitude', Clinical Orthopaedics and Related Research ${ }^{\circledR}$. Springer US. doi: 10.1007/s11999-016$5100-0$

Liebling, A. (2008) 'Incentives and earned privileges revisited: Fairness, discretion, and the quality of prison life', Journal of Scandinavian Studies in Criminology and Crime Prevention, pp. 25-42. doi: 10.1080/14043850802450773.

Pheny, S., Raymondalexas, C. and Rahmat, I. (2014) Association between adversity quotient and quality of life among drug abusers in Narcotics Penitentiary Class IIa Yogyakarta. Universitas Gadjah Mada.

'Sistem Database Pemasyarakatan. Laporan 
Jurnal Ilmiah Kesehatan Vol XIII, No 1, Maret 2020 ISSN 1978-3167, E-ISSN 2580-135X penghuni lapas' (2017).

Sistem Database Pemasyarakatan. Laporan penghuni lapas (2018).

'Sistem Database Pemasyarakatan. Laporan penghuni lapas' (2019).

Vahedi, S. (2010) 'World Health Organization quality of life scale (WHOQOL-BREF): Analyses of their item response theory properties based on the graded responses model', 5, pp. 140-153.

Ventegodt, S., Merrick, J. and Andersen, N. J. (2003) 'Quality of life theory II. Quality of life as the realization of life potential: A Scientific World JOURNAL, 3, pp. 10411049. doi: 10.1100/tsw.2003.83.

WHO (1996) 'WHOQOL-BREF introduction, administration, scoring, and generic version of the assessment', (December).

WHO (1998) 'The World Health Organization quality of life assessment (WHOQOL): Development and general psychometric properties', 46(12).

WHOQOL (1998) 'Development of the World Health Organization WHOQOL-BREF quality of life assessment', pp. 551-558. 